\title{
More wicked ways with hormones
}

The European Commission has hung an intellectual millstone around its neck by banning the use of bovine growth hormone in growing cattle. The European Parliament has a duty to put it straight.

VISIONARIES who proclaim that the United States of Europe is no further away than 1992, when the European Economic Community will constitute the single market originally decreed by the Treaty of Rome, habitually overlook the still-glaring differences between Europe and the United States. True, Europe has a president (now M. Jacques Delors), but does not require that he should be elected as $\mathrm{Mr}$ George Bush has been. And while the members of the European Commission (now 17 strong) are roughly analogous to members of a cabinet, they too are merely nominated every four years by the political heads of member governments. There is also a singlechamber European Parliament, the equivalent of the US Congress, which does suffer periodic re-election (next in June this year), but the opinion even among ardent Europeans is that the parliament will have to win influence in European affairs by demonstrating its value and good sense. The same Europeans will therefore be dismayed by one development last week - the decision of a parliamentary committee to support and even to reinforce the regulations that prohibit the use of bovine growth hormones in the fattening of cattle.

The circumstances are quite scandalous. Since the beginning of 1988, the sale in Europe of beef grown with the use of bovine growth hormone has been prohibited by a directive (with the force of law) of the European Commission. Although the measure has been justified as a means of protecting people's health, there is literally no evidence that beef produced with growth hormone is a hazard to health, but every reason to believe that bovine growth hormone in cattle is rapidly metabolized (which is why it helps cattle to grow more quickly). So why ban its use? Because Europe's system of support for agriculture is a means of over-producing all kinds of commodities, beef included, and because those administering the system were ready to clutch at any straw to prevent further surpluses of beef. What more natural than an alliance with the green extremists to keep the hormone out of use? Although imports of beef from the United States were exempted from restriction during 1988, this year began with an acrimonious trade dispute between Europe and the United States that rumbles on.

Now the European Parliament has entered the fray, but discreditably. Last week its environment committee in Luxembourg issued the gist of a report supporting the European Commission's ban and urging more vigilance in tracking down now-illicit uses of these materials. The opportunity for extricating the Commission from the pit of unreason it had dug for itself has been spurned in the face of informed opinion and despite the diplomatic damage the ban has already caused. In the short run, the consequence will be more trouble. Unless the full parliament rejects the opinion of its committee in the discussion arranged for April, it will find that in the long run, it has much less influence than it might have won by acting sensibly, which should worry ardent Europeans, green and not-so-green.

\section{Budgets off balance}

Budget problems in Britain, the Soviet Union and United States may have different origins - but one solution.

AMONG the quainter British customs is the annual ritual in which a person called the Chancellor of the Exchequer (now Mr Nigel Lawson) tells the House of Commons what taxes he plans to increase or decrease. The procedure is the inverse of what happens in most other places. where a government's annual budget is a statement of what it plans to spend coupled with a comparison of total spending and total revenue. In Britain, the spending estimates appear first, as fiat. That is why Lawson's performance last week (his sixth) has generally been written off as "dull" for, breaking with recent form, he offered neither tax breaks nor further imposts, except marginally.

But there is more than that to say. The British government is in the enviable position that its accounts are in surplus. In the year ending this month, there will be a surplus of $£ 14,000$ million. With the over-cautious forecast that next year's surplus will be the same, the British government could liquidate its entire debt within a decade. But is there nothing better to do with surplus funds than pay off debts? Not on British experience in the past few years. Putting more money in British pockets (either by reducing taxes or spending money) seems either to increase imports or industrial costs (through higher wages) - or both. Britain already has a trade deficit comparable with its budget surplus and slightly larger (as a percentage of Gross Domestic Product) than that of the United States. And inflation is pushing 8 per cent, so that interest rates have increased and sterling has 